\title{
The Socio-Economic Status of Women Entrepreneurs in Salem District of Tamil Nadu
}

\author{
T. Sasikala* \\ Assistant Professor of Economics, Sri Sarada College for Women, Salem, \\ India; geothangam@gmail.com
}

\begin{abstract}
The women entrepreneurship has become quite popular all over the world during the few past decades. The women entrepreneurs have proved their mettle that they are equally competent as their male counterparts. They have been running their enterprises successfully by taking active part in the business. They are able to balance the domestic affairs and the business affairs to a great extent. Their socio-economic status is relied upon the enterprises run by them. Salem District is one of the large districts where more number of women entrepreneurs is found and a lot of enterprises are run by them. The size of enterprises run by women entrepreneurs is ranging from small and medium to large size enterprises. The demographic profile of the women entrepreneurs, their attitude towards running their own enterprises, their socioeconomic status and problems faced by them have been examined in this paper.
\end{abstract}

Keywords: Attitude, Demographic Profile, Problems, Socio Economic Status, Women Entrepreneurs

\section{Introduction}

Women have been proving that they are equally competent as the men in every field. Women's capabilities have been accepted and they have been elevated in all walks of life. It is an indication that women are successful in running their own enterprises also. Women entrepreneurs run enterprises which are ranging from small and medium to large size enterprises. It leads to economic independence of women and women empowerment.

The women-led enterprises are started with a capital contributed by them either out of their own earnings or savings from the amount given to them by their husband. When they get support from the family members they are more successful. They could manage both the business affairs as well as domestic affairs.

Women entrepreneurship plays a crucial role in women empowerment. They contribute capital, run the business, take the risk and get the profits of the business carried on by them. Obviously, their socio-economic status increases in the society.

\section{Review of Literature}

Santha [1] conducted a study on socio-economic status of women entrepreneurs in Kerala and Tamil Nadu and found that they were similar in respect of their decision making power, power exercised in business, degree of involvement in social activities and the reasons for such involvement.

Jawaharlal Nehru and Shubhra Bhardwaj [2] analyzed the issues and problems of women entrepreneurs in India. They have concluded that male-dominated culture has been the major source of challenges faced by women entrepreneurs.

Ajit Borah [3] made an attempt to understand whether the level of education helps women entrepreneurs to start their enterprises in Morigaon District and observed that

*Author for correspondence 
most of the women entrepreneurs preferred to start their own enterprises rather than pursuing higher education because of poor economic condition of their families.

\section{Statement of the Problem}

Women are encouraged to become entrepreneurs. Both the central and state governments support the women entrepreneurs by providing technical assistance and financial assistance through the implementation of various schemes. Despite support from several sources it is still questionable whether the women entrepreneurs are successful. In Tamil Nadu, Salem District contributes more towards the economic development of the state through women entrepreneurs. In this study, attempt has been made to analyze the socio-economic status of women entrepreneurs in Salem District.

\section{Objectives of the Study}

The present study is undertaken to analyze the social and economic status of women entrepreneurs in the selected area - Salem District. The following are the objectives of the study:

- To understand the demographic profile of the women entrepreneurs

- To analyze the attitude of women entrepreneurs towards running own enterprises

- To assess the socio-economic status of women entrepreneurs

- To identify the problems faced by women entrepreneurs

- To offer suggestions to improve their socio-economic status

\section{Hypotheses of the Study}

For the purpose of present study, the under-mentioned hypotheses have been framed and tested by applying appropriate statistical tools.

- There is no significant relationship between demographic profile of women entrepreneurs and their attitude towards running own enterprises.

- The relationship between type of enterprises and socio economic status of women entrepreneurs is not significant.
- The size of enterprises and problems faced by women entrepreneurs are insignificantly related.

\section{Research Methodology}

\subsection{Data Source}

This study is based on primary data.

\subsection{Data Collection}

A structured questionnaire was prepared and administered among the sample respondents to collect data.

\subsection{Sampling Technique and Size}

Stratified random sampling method was adopted. Accordingly, women entrepreneurs in Salem District were divided into three strata on the basis of type of enterprises - manufacturing, trading and service enterprises. Samples were selected from each stratum equally. The sample size for the present study was 300 comprising 100 respondents each from manufacturing enterprises, trading enterprises and service enterprises.

\subsection{Tools of Analysis}

Appropriate statistical tools like percentage analysis, mean, standard deviation, range, chi square test and Henry Garrett Ranking technique were applied to analyse the data and to draw valid conclusions.

\section{Analysis and Interpretation}

In order to fulfill the objectives of the study, the analysis has been divided into four parts, viz., demographic profile, attitude towards running own enterprises, socio-economic status and problems faced by women enterprises.

\subsection{Demographic Profile}

The demographic profile of the women entrepreneurs has been analyzed with the variables such as age group, marital status, nature of family, type of enterprise, length of service and income per month. For each of these variables, percentages, mean, standard deviation and range values have been computed and presented. In this regard, 
the attitude of women entrepreneurs has been given in eight statements - I feel happy to run my own enterprise, I have learned marketing skills, I have learned financial strategies, I have learned to manage human resources, I have improved my leadership skills, I have improved my communicative skills, I have learned to solve problems and I have learned to make quick decisions. The respondents were asked to give their opinions in a Likert's five-point rating scale - strongly agree, agree, neutral, disagree and strongly disagree. These responses were assigned scores as 5 for strongly agree, 4 for agree, 3 for neutral, 2 for disagree and 1 for strongly disagree. Based on the total score of attitude towards running own enterprises, the mean, standard deviation and range values have been computed.

It is understood from Table 1 that out of 300 respondents, 23.00 per cent of them belonged to the age group of below 25 years whose mean score of attitude towards running own enterprise was found to be 21.17 which ranged between 11 and 33 with a standard deviation of 5.08. The respondents belonging to the age group of 25-35 years constituted 46.33 per cent of the total respondents. The mean score of their attitude was found to be 20.73 and the standard deviation was 4.07 with their attitude score ranging from 11 to 29 . It is observed that out of 300 respondents, 23.33 per cent of them belonged to the age group of 35-45 years whose mean score of attitude towards running own enterprise was found to be 22.46 which ranged between 14 and 30 with a standard deviation of 4.38 . The respondents belonging to the age group of above 45 years constituted 7.34 per cent of the total respondents. The mean score of their attitude was found to be 25.23 and the standard deviation was 4.76 with their attitude score ranging from 17 to 35 . It denotes that the majority of women entrepreneurs ( 46.33 per cent) belonged to the age group of 25-35 years.

Table 2 reveals that out of 300 respondents, 34.67 per cent of them were single respondents whose mean score of attitude towards running own enterprise was found to

Table 1. Age group of women entrepreneurs

\begin{tabular}{|c|c|c|c|c|c|c|}
\hline Age group & $\mathrm{N}$ & $\%$ & Mean & Minimum & Maximum & Std. Deviation \\
\hline Below 25 years & 69 & 23.00 & 21.17 & 11 & 33 & 5.08 \\
\hline $25-35$ years & 139 & 46.33 & 20.73 & 11 & 29 & 4.07 \\
\hline $35-45$ years & 70 & 23.33 & 22.46 & 14 & 30 & 4.38 \\
\hline Above 45 years & 22 & 7.34 & 25.23 & 17 & 35 & 4.76 \\
\hline Total & 300 & 100 & 21.57 & 11 & 35 & 4.59 \\
\hline
\end{tabular}

Source: Primary data

Table 2. Marital status of women entrepreneurs

\begin{tabular}{|c|c|c|c|c|c|c|}
\hline Marital Status & $\mathrm{N}$ & $\%$ & Mean & Minimum & Maximum & Std. Deviation \\
\hline Single & 104 & 34.67 & 21.30 & 11 & 32 & 4.43 \\
\hline Married & 196 & 65.33 & 21.71 & 11 & 35 & 4.67 \\
\hline Total & 300 & 100 & 21.57 & 11 & 35 & 4.59 \\
\hline
\end{tabular}

Source: Primary data 
be 21.30 which ranged between 11 and 32 with a standard deviation of 4.43. The married respondents constituted 65.33 per cent of the total respondents. The mean score of their attitude was found to be 21.71 and the standard deviation was 4.67 with their attitude score ranging from 11 to 35 . It implies that more married respondents have become entrepreneurs than the single respondents.

According to Table 3, out of 300 respondents, 41.33 per cent of them were nuclear family respondents whose mean score of attitude towards running own enterprise was found to be 21.69 which ranged between 11 and 35 with a standard deviation of 4.58 . The joint family respondents constituted 58.67 per cent of the total respondents. The mean score of their attitude was found to be 21.48 and the standard deviation was 4.61 with their attitude score ranging from 11 to 33 . It denotes that the most of the women entrepreneurs were living in joint families.

It could be observed from Table 4 that out of 300 respondents, 33.33 per cent of them were running

Table 3. Nature of family of women entrepreneurs

\begin{tabular}{|c|c|c|c|c|c|c|}
\hline Nature of family & $\mathrm{N}$ & $\%$ & Mean & Minimum & Maximum & $\begin{array}{c}\text { Std. } \\
\text { Deviation }\end{array}$ \\
\hline Nuclear family & 124 & 41.33 & 21.69 & 11 & 35 & 4.58 \\
\hline Joint family & 176 & 58.67 & 21.48 & 11 & 33 & 4.61 \\
\hline Total & 300 & 100 & 21.57 & 11 & 35 & 4.59 \\
\hline
\end{tabular}

Source: Primary data

Table 4. Type of enterprise of women entrepreneurs

\begin{tabular}{|c|c|c|c|c|c|c|}
\hline Type of Enterprise & $\mathrm{N}$ & $\%$ & Mean & Minimum & Maximum & Std. Deviation \\
\hline Manufacturing & 100 & 33.33 & 21.33 & 13 & 32 & 4.18 \\
\hline Trading & 100 & 33.33 & 21.91 & 11 & 35 & 5.06 \\
\hline Service & 100 & 33.34 & 21.46 & 11 & 33 & 4.50 \\
\hline Total & 300 & 100 & 21.57 & 11 & 35 & 4.59 \\
\hline
\end{tabular}

Source: Primary data

Table 5. Length of service of women entrepreneurs

\begin{tabular}{|c|c|c|c|c|c|c|}
\hline Length of service & $\mathrm{N}$ & $\%$ & Mean & Minimum & Maximum & Std. Deviation \\
\hline Below 2 years & 123 & 41.00 & 21.20 & 11 & 33 & 4.56 \\
\hline 2 - 4 years & 124 & 41.33 & 21.03 & 11 & 30 & 4.39 \\
\hline 4 - 6 years & 29 & 9.67 & 22.45 & 13 & 29 & 4.44 \\
\hline Above 6 years & 24 & 8.00 & 25.17 & 17 & 35 & 4.41 \\
\hline Total & 300 & 100 & 21.57 & 11 & 35 & 4.59 \\
\hline
\end{tabular}

Source: Primary data 
manufacturing enterprises whose mean score of attitude towards running own enterprise was found to be 21.33 which ranged between 13 and 32 with a standard deviation of 4.18. The trading enterprise owners constituted 33.33 per cent of the total respondents. The mean score of their attitude was found to be 21.91 and the standard deviation was 5.06 with their attitude score ranging from 11 to 35 . It is further inferred that in respect of 33.34 per cent of them running service enterprises, the mean score of attitude towards running own enterprise was found to be 21.46 which ranged between 11 and 33 with a standard deviation of 4.50 .

It is evinced from Table 5 that out of 300 respondents, 41.00 per cent of them have an experience of below 2 years whose mean score of attitude towards running own enterprise wasfound to be 21.20 which ranged between 11 and 33 with a standard deviation of 4.56 . The respondents with 2-4 years of experience constituted 41.33 per cent of the total respondents. The mean score of their attitude was found to be 21.03 and the standard deviation was 4.39 with their attitude score ranging from 11 to 30. It is observed that out of total respondents, 9.67 per cent of them had 4-6 years of experience whose mean score of attitude towards running own enterprise was found to be 22.45 which ranged between 13 and 29 with a standard deviation of 4.44. The respondents having above 6 years of experience constituted 8.00 per cent of the total respondents. The mean score of their attitude was found to be 25.17 and the standard deviation was 4.41 with their attitude score ranging from 17 to 35 . It denotes that the majority of women entrepreneurs (41.33 per cent) had a length of service of 2 to 4 years.
According to Table 6 out of 300 respondents, 41.34 per cent of them have an income of below Rs. 10000 per month whose mean score of attitude towards running own enterprise was found to be 20.94 which ranged between 11 and 33 with a standard deviation of 4.80 . The respondents with a monthly income of Rs. 10000 to Rs.20000 constituted 11.33 per cent of the total respondents. The mean score of their attitude was found to be 21.25 and the standard deviation was 4.24 with their attitude score ranging from 14 to 30 . It is observed that out of total respondents, 2.33 per cent of them had Rs. 20000 to Rs. 30000 of monthly income whose mean score of attitude towards running own enterprise was found to be 24.71 which ranged between 23 and 28 with a standard deviation of 1.60. The respondents having above Rs. 30000 of income per month constituted 43.00 per cent of the total respondents. The mean score of their attitude was found to be 22.10 and the standard deviation was 4.49 with their attitude score ranging from 11 to 35 . It indicates that the majority of women entrepreneurs (43.00 per cent) had a monthly income of above Rs.30000.

\subsection{Attitude towards Running Own Enterprises}

The attitude towards running own enterprises as defined in the eight given statements was assigned scores and the scores between 8 and 19 were considered as low level attitude, the scores between 20 and 30 were taken as medium level attitude and the scores ranging between 31 and 40 were deemed as high level attitude. The relationship between demographic profile and attitude

Table 6. Income per month of women entrepreneurs

\begin{tabular}{|c|c|c|c|c|c|c|}
\hline Income per month & $\mathrm{N}$ & $\%$ & Mean & Minimum & Maximum & Std. Deviation \\
\hline Below Rs.10000 & 124 & 41.34 & 20.94 & 11 & 33 & 4.80 \\
\hline Rs.10000 - Rs.20000 & 40 & 13.33 & 21.25 & 14 & 30 & 4.24 \\
\hline Rs.20000 - Rs.30000 & 7 & 2.33 & 24.71 & 23 & 28 & 1.60 \\
\hline Above Rs.30000 & 129 & 43.00 & 22.10 & 11 & 35 & 4.49 \\
\hline Total & 300 & 100 & 21.57 & 11 & 35 & 4.59 \\
\hline
\end{tabular}

Source: Primary data 
Table 7. Demographic variables and level of attitude

\begin{tabular}{|c|c|c|c|c|}
\hline Factors & Chi square value & DF & P value & Result \\
\hline Age group and Level of attitude & 29.067 & 6 & 0.000 & Significant @ 1\% \\
\hline Marital status and Level of attitude & 0.099 & 2 & 0.952 & Not Significant \\
\hline Nature of family and Level of attitude & 0.342 & 2 & 0.843 & Not Significant \\
\hline Type of enterprise and Level of attitude & 1.969 & 4 & 0.741 & Not Significant \\
\hline Length of service and Level of attitude & 21.241 & 6 & 0.002 & Significant @ 1\% \\
\hline Income per month and Level of attitude & 9.816 & 6 & 0.133 & Not Significant \\
\hline
\end{tabular}

Source: Computed from Primary data

towards running own enterprises has been analyzed by testing the hypothesis using chi square test.

From Table 7, it could be well understood that the level of attitude of women entrepreneurs towards running their own enterprises has been influenced significantly by their age group and length of service. The other demographic variables like marital status, nature of family, type of enterprise and income per month did not have any significant influence on the attitude of women entrepreneurs. It implies that the attitude of women entrepreneurs towards running their own enterprises varies from one person to another significantly according to their age group, i.e., as the age group of women entrepreneurs varies, their attitude towards running own enterprises also varies. Similarly, the attitude of women entrepreneurs towards running own enterprises is likely to vary according to the variation in the length of service.

Table 8. Type of enterprise and socio economic status

\begin{tabular}{|c|c|c|c|}
\hline Factors & F & P value & Result \\
\hline I am a member of social clubs & 0.27 & 0.76 & NS \\
\hline I have served as an office bearer in social clubs & 0.84 & 0.43 & NS \\
\hline I help the poor students/needy people financially & 0.18 & 0.84 & NS \\
\hline I could speak in a gathering & 7.61 & 0.00 & $* *$ \\
\hline I have a personal bank account & 0.87 & 0.42 & NS \\
\hline I have bought land/building after becoming entrepreneur & 0.93 & 0.40 & NS \\
\hline I have bought a car/two wheeler after becoming entrepreneur & 10.13 & 0.00 & $* *$ \\
\hline I have bought domestic appliances after becoming entrepreneur & 0.86 & 0.42 & NS \\
\hline I have employed servant maid for domestic works & 2.29 & 0.10 & NS \\
\hline I have visited many places after becoming entrepreneur & 0.52 & 0.60 & NS \\
\hline
\end{tabular}

NS - Not Significant $* *$ Significant @ 1\% level 


\subsection{Socio-economic Status}

The socio-economic status of women entrepreneurs in Salem District has been measured in terms of ten prescribed statements - I am a member of social clubs, I have served as an office bearer in social clubs, I help financially the poor students/needy people, I could speak in a gathering, I have a personal bank account, I have bought land/building after becoming entrepreneur, Ihaveboughtcar/two wheelerafterbecoming entrepreneur, I have bought domestic appliances after becoming entrepreneur, I have employed servant maid for domestic works and I have visited many places after becoming entrepreneur.

According to Table 8, there was a statistically strong and significant relationship between type of enterprise and ability of women entrepreneurs to speak in a gathering. It implies that the ability of women entrepreneurs to speak in a gathering varies from one type of enterprise to another type of enterprise. The relationship between type of enterprise and purchase of car/two wheeler after becoming entrepreneurs is also statistically significant. It denotes that the women entrepreneurs have bought car/two wheeler after becoming entrepreneurs. However, there was a significant variation in buying car/two wheeler by women entrepreneurs with reference to type of enterprise. It is to be noted that since the $\mathrm{p}$ values of all other factors were greater than 0.05 , the relationship between type of enterprise and all the other factors was not significant.

\subsection{Problems Faced by Women Entrepreneurs}

The problems faced by women entrepreneurs while running their own enterprises have been analyzed in this paper. For this purpose, difficulties with administrative staff, frequent arguments with labours, lack of support from husband/family members, feeling restlessness quite often, inability to spend time with family, inability to compete with men entrepreneurs, difficulties in relationships with customers/suppliers, lack of technicalknowledgeandlack of negotiating skills have been considered as the common problems faced by the women entrepreneurs.

Table 9 portrays that the first and foremost problem of women entrepreneurs as indicated by the total and mean scores of Garrett ranking technique was the frequent arguments with labours, which is followed by difficulties with administrative staff and feeling of restlessness quite often. The fourth problem as identified by

Table 9. Problems faced by women entrepreneurs

\begin{tabular}{|c|c|c|c|}
\hline Problems & $\begin{array}{c}\text { Total } \\
\text { Score }\end{array}$ & $\begin{array}{c}\text { Mean } \\
\text { Score }\end{array}$ & Rank \\
\hline Difficulties with administrative staff & 16998 & 56.66 & II \\
\hline Frequent arguments with labours & 17243 & 57.48 & I \\
\hline Lack of support from husband/family members & 15935 & 53.12 & IV \\
\hline Feeling of restlessness quite often & 16837 & 56.12 & III \\
\hline Inability to spend time with family & 13692 & 45.64 & VII \\
\hline Inability to compete with men entrepreneurs & 14488 & 48.29 & V \\
\hline Difficulties in relationships with customers/suppliers & 12078 & 40.26 & IX \\
\hline Lack of technical knowledge & 12393 & 41.31 & VIII \\
\hline Lack of negotiating skills & 14136 & 47.12 & VI \\
\hline
\end{tabular}

Source: Computed from Primary data 
the women entrepreneurs was the lack of support from husband/family members and the fifth problem was the inability of women entrepreneurs to compete with men entrepreneurs while the sixth problem as pointed out by women entrepreneurs was lack of negotiating skills. Inability to spend time with family has been ranked as the seventh problem of women entrepreneurs whereas lack of technical knowledge and difficulties in relationships with customers/suppliers were the eighth and ninth ranked problems respectively.

\section{Findings of the Study}

The following are the key findings of the study:

- The most of the women entrepreneurs in Salem District were found to be young and in the age group of 25 to 35 years while the majority of them were married and were living in joint families.

- It is found that around 80 per cent of the women entrepreneurs had an experience of below 2 years and 2 to 4 years whereas the income per month of the majority of women entrepreneurs was found to be above Rs. 30000 .

- The attitude of women entrepreneurs has been found to be influenced significantly by the age and length of service of women entrepreneurs.

- The socio-economic status of women entrepreneurs has increased to a considerable extent. The type of enterprise has influenced the socio-economic status of women entrepreneurs with reference to speaking in a gathering and buying a car/two wheeler after becoming entrepreneur.

- It is observed that the frequent arguments with labours and difficulties with administrative staff have been the most important problems faced by women entrepreneurs. Feeling of restlessness quite often and lack of support from husband/ family members have been ranked in the third and fourth orders respectively.

\section{Suggestions}

Based on the major findings of the study, the researcher has put forth the following suggestions which have been found to be appropriate and relevant for improving the socio- economic status of women entrepreneurs:

- More number of very young women i.e., below 25 years of age should be encouraged to start and run enterprises according to their skills and abilities.

- Entrepreneurship development programme should be conducted exclusively for the unmarried women and they shall be motivated to become entrepreneurs.

- The budding entrepreneurs should be provided training programmes for communicative skills and negotiating skills.

- The women entrepreneurs should be given opportunities to participate in the meetings and speak in the gathering to help them improve their leadership skills.

- Stress management programmes should be conducted for the welfare of women entrepreneurs to avoid arguments with labours, difficulties with administrative staff and the feeling of restlessness.

\section{Conclusion}

The socio-economic status of women entrepreneurs in Salem District was aimed to be studied in the research work. Accordingly, three types of women entrepreneurs, i.e., those who are running manufacturing enterprises, trading enterprises and service enterprises were selected and the data required for the study have been obtained by using a structured questionnaire. The results of the study show that the socio-economic status of women entrepreneurs has increased to a considerable extent. By providing adequate support - technically, financially and psychologically, the socio-economic status of women entrepreneurs in Salem District would further be improved.

\section{References}

1. Santha S. "Socio-economic Status of Women Entrepreneurs in Kerala and Tamil Nadu, Prabandhan", Indian Journal of Management, Vol. 6(6), pp. 32-47, 2013 Jun.

2. Nehru J., Bhardwaj S. Women Entrepreneurship in India: Issues and Problems "You can tell the condition of a nation by looking at the status of its women", Spectrum: A Journal 
of Multidisciplinary Research, Vol. 2(7), pp. 8-16, 2013 Jul.

3. Borah A. "Socio- Economic Status of Women Entrepreneurship - A Case Study in Morigaon District in
Assam", IOSR Journal of Humanities and Social Science, Vol. 19(7), pp. 26-33, 2014. 